\title{
Straw management effects on sugarcane growth, nutrient cycling and water use in the Brazilian semiarid region
}

\author{
Carlos Andre Alves de Souza ${ }^{1}$ (D), Thieres George Freire da Silva ${ }^{1}$ (D), Luciana Sandra Bastos de \\ Souza $^{1}$ (D), Magna Soelma Beserra de Moura² ${ }^{\text {ID }}$, Paulo Pedro Silva ${ }^{1}$ (D), Fábio Ricardo Marin ${ }^{3, \star ~(i D ~}$ \\ 1. Universidade Federal Rural de Pernambuco - Unidade Acadêmica Serra Talhada - Serra Talhada (PE), Brazil. \\ 2. Empresa Brasileira de Pesquisa Agropecuária - Embrapa Semiárido - Petrolina (PE), Brazil. \\ 3. Universidade de São Paulo - Escola Superior de Agricultura “Luiz de Queiroz” - Departamento de Engenharia de \\ Biossistemas - Piracicaba (SP), Brazil.
}

\begin{abstract}
It was evaluated how straw management modifies the development, growth, nutrient cycling and crop water productivity of sugarcane in the semiarid region of Brazil. The experiment was carried out using two plots with 5 ha each, being one without straw on the soil surface and one with $27.2 \mathrm{Mg} \cdot \mathrm{ha}^{-1}$ covering the soil. Sugarcane growth and development and straw decomposition coefficient were evaluated, whereas the industrial yield, juice quality, dry matter partitioning, and crop water productivity were determined at harvesting.

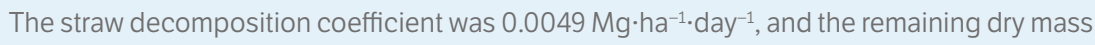
was equal to $24 \%$. The straw affected the sugarcane growth and development until the first 100 days. The individual internode volume can be adopted as an indicator of the effect of straw on sugarcane growth because the internode volumes up to the sixth position in the with-straw treatment crop were lower than in the no-straw treatment, which was not observed in other variables of the stalks. Keeping straw on the soil surface reduced the crop lodging. Yield and juice quality were not affected, but crop water productivity was increased by keeping sugarcane straw in the field.
\end{abstract}

Key words: trash blanket, decomposition, evapotranspiration.
Received:

May 18, 2020

Accepted:

Sep. 1, 2020

Section Editor:

Osvaldo Guedes Filho

${ }^{*}$ Corresponding author: fabio.marin@usp.br

\section{INTRODUCTION}

Brazil is one of the world's largest producers of sugarcane and its by-products, and the sugarcane yield depends on the volume of water received, type of soil, crop cycle, cultivar, climate, and the irrigation system adopted (Marin et al. 2020; Marin and Jones 2014; Silva et al. 2014 a, b). Because of technological advances in irrigation, areas are cultivated with sugarcane in the Brazilian semiarid region all year round. Recently, furrow irrigation systems with low application efficiency have been replaced by subsurface drip systems, improving the water use efficiency and increasing the crop yield.

The stalk juice is used for production of sugar or ethanol, whereas the straw and bagasse can be converted into cellulosic ethanol, burned for energy production, or kept in the field as mulch (Fortes et al. 2012). There is a tendency to keep straw in the field as a management practice to improve agricultural yield, reduce greenhouse gas emissions and save water (Aquino et al. 2018; Bu et al. 2013; Kader et al. 2017; Olivier and Singels 2015).

The presence of straw, commonly referred to as green cane trash blanketing, on sugarcane fields reduces the need for irrigation, erosion risk, weed emergence, and carbon emission (Hu et al. 2018; Sousa Junior et al. 2018); it improves microbiota and soil physical properties (Souza et al. 2005), releases nutrients (as nitrogen) into the soil (Sousa Junior et al. 2018; Vitti et al. 2008; Costa et al. 2014), and modifies the microclimate (Sandhu et al. 2013; Silva et al. 2019), besides increasing the crop water productivity (Olivier and Singels 2012; 2015; Vianna et al. 2020). On the other hand, excess straw 
changes crop growth and development (Olivier and Singels 2012; 2015; Marin et al. 2014) by increasing the risk of fire and infestation of pests and diseases and impairing sprouting (Awe et al. 2015).

Crop responses to the presence of straw on soil surface depends on the interaction of genotype, soil, climate, and management practices (Ramburan and Nxumalo 2017; Marin et al. 2014). The management of straw depends on its decomposition rate and persistence in the field, which are linked to C:N ratio of plant material (Awe et al. 2015; Fortes et al. 2012).

The Brazilian semiarid region is characterized by high temperatures and low rainfall (Moura et al. 2007), which favor the straw decomposition rate in irrigated fields (Thongjoo et al. 2005; Zhou et al. 2016). It represents 18\% of the Brazil area and has c.a. 18,000 irrigated hectares (IBGE 2019). The water use and water productivity in this region has become even more important in the last decade since there is a dispute over irrigation water with other crops (Teixeira 2010; Teixeira et al. 2013).

Despite the importance of this region, no study investigating the sugarcane growth and development, water use and straw management effects in the tropical semiarid region of Brazil is known. In such environmental conditions, straw is supposed to decompose at higher rates, and the adverse effects of excessive mulching on the crop can be lower than those observed in the subtropical climate (Aquino et al. 2018; Lisboa et al. 2018). To fill in the knowledge gap about the sugarcane crops in the Brazilian semiarid and the effect of straw on the crop, an experiment was conducted to evaluate the effects of straw management on the growth, development, and crop water productivity of sugarcane in the Brazilian semiarid region.

\section{MATERIAL AND METHODS}

\section{Site description, treatments, and crop management}

The experiment was carried out in a sugarcane field (9 $29^{\prime} 51^{\prime \prime}$; $40^{\circ} 21^{\prime} 43^{\prime \prime} \mathrm{W} ; 400 \mathrm{~m}$ a.s.l.) in the Brazilian semiarid region. The soil of the experimental area is a Vertisol type (Embrapa 2013). The climate in the region is semiarid, with rainfall of $513 \mathrm{~mm} \cdot$ year $^{-1}$, distributed between summer and autumn, and atmospheric demand of $1,887 \mathrm{~mm} \cdot y^{2} \mathrm{r}^{-1}$, according to the historical series from 1965 to 2015.

The sugarcane cultivar used in the experiment was VAT 90-212, planted in February 2013, using whole stalks with 12 buds on average per linear meter, in furrows $0.2 \mathrm{~m}$ deep arranged in double rows spaced at $0.7 \times 1.3 \mathrm{~m}$. The first harvest was performed after 18 months from planting and the second (ratoon), after 12 months, on August 21, 2015. Then this study was started and conducted until July 28, 2016 (342 days).

Sugarcane with-straw treatment was imposed at two levels of soil cover - one with and the other without straw (no-straw treatment) on soil surface. There were two adjacent experimental plots (about 5 ha) harvested manually on August 21, 2015 - the first one burning soon after and the second one without burning where straw was kept. Straw level was set between August 31 and September 10, 2015, yielding $27.2 \mathrm{Mg}$ dry mass $\cdot \mathrm{ha}^{-1}$ covering $100 \%$ soil surface. On average, straw composition was $48 \mathrm{~g} \mathrm{C} \cdot \mathrm{kg}^{-1}$ and $0.41 \mathrm{~g} \mathrm{~N} \cdot \mathrm{kg}^{-1}$. The initial amount of straw deposited in the field $\left(27.2 \mathrm{Mg} \cdot \mathrm{ha}^{-1}\right)$ was within the range

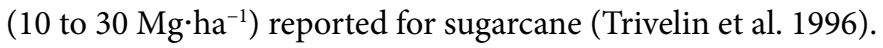

This study used a subsurface drip irrigation system with self-compensating labyrinth-type emitters $\left(1.6 \mathrm{~L} \cdot \mathrm{h}^{-1}\right)$, spaced at $0.5 \mathrm{~m}$ and embedded in the hoses, which were buried at $0.2 \mathrm{~m}$ depth. The amount of irrigation water applied was based on the reference evapotranspiration ( $\mathrm{ET}_{0}$ ) and crop coefficient, according to Silva et al. (2012 a). To estimate ET, Penman Monteith's method (Allen et al. 1998) and weather data were used. The weather data were collected from an automated weather station (ET107, Campbell Scientific, Logan UT, USA) at $800 \mathrm{~m}$ from the experimental plots, with sensors (global solar radiation, CS305 sensor; temperature and air relative humidity, HMP60 sensor; rain, TR525 sensor; wind speed, 034B sensor; wind direction, WindSonic-2D sensor) connected to a CR1000 datalogger, taking readings every $60 \mathrm{~s}$ and recording the average every $30 \mathrm{~min}$. Total irrigation volume was $1,557 \mathrm{~mm}$, and rainfall was $345 \mathrm{~mm}$, resulting in an applied water depth of $1,937 \mathrm{~mm}$ at 342 days after cutting (DAC). During the crop cycle, fertigation was performed with 
$420 \mathrm{~kg} \mathrm{~N} \cdot \mathrm{ha}^{-1}, 6.1 \mathrm{~kg} \mathrm{P}_{2} \mathrm{O}_{5} \cdot \mathrm{ha}^{-1}, 3.7 \mathrm{~kg} \mathrm{~K} \mathrm{O} \cdot \mathrm{ha}^{-1}$, and $2.5 \mathrm{~kg} \cdot \mathrm{ha}^{-1}$ of commercial micronutrient product with $1.8 \% \mathrm{~B} ; 0.8 \%$ $\mathrm{Cu} ; 3.0 \% \mathrm{Fe} ; 2.0 \% \mathrm{Mn} ; 0.10 \% \mathrm{Mo}$, and $9.0 \% \mathrm{Zn}$. Phytosanitary treatment for the control of sugarcane pests and diseases was always performed.

\section{Straw decomposition, carbon and nitrogen release, extraction and exports}

Measurements of straw amount were taken at 20, 105, 195, 258, 307, and 342 DAC, from September 11, 2015 to July 28 , 2016. For this, four samples of $1.0 \mathrm{~m}^{2}$ of the crop residue were weighed individually. The samples were fractionated and dried in a forced-air ventilation oven $\left(60^{\circ} \mathrm{C}\right)$ for $48 \mathrm{~h}$ until they obtained constant weight. The remaining straw dry mass (RSDM) was used to fit the exponential model $\mathrm{Y}=\mathrm{a} \mathrm{e}^{-\mathrm{kDAC}}$, where $\mathrm{a}$ is the initial RSDM $\left(\mathrm{Mg}^{-h^{-1}}\right)$ and $\mathrm{k}$ is the straw decomposition coefficient $\left(\right.$ day $\left.^{-1}\right)$. The model was used to estimate the straw decomposition rate, average half-life $\left(t_{1 / 2}=\ln (2) / k\right.$, in days), the time required to decompose $50 \%$ of the initial RSDM, time at which $5 \%$ of the dry mass remained $\left(t_{5 / 100}=3 / \mathrm{k}\right.$, in days), and the time for new straw deposition (tnsd, in days).

Subsamples of the above ground biomass and straw were milled in a Wiley-type mill to quantify carbon and nitrogen content according to Silva and Queiroz (2002). The amounts of C and N released by straw were calculated from the difference of $\mathrm{C}$ and $\mathrm{N}$ contents at the beginning and at end of the cycle, considering the amount of decomposed straw. The stock of $\mathrm{C}$ and $\mathrm{N}$ were obtained by the product of the $\mathrm{C}$ and $\mathrm{N}$ content and the accumulation of dry biomass by the plant. In the no-straw treatment, it was assumed that the release of $\mathrm{C}$ and export of $\mathrm{N}$ occurs from the harvesting of the plant aerial part. In the with-straw treatment, the release of $\mathrm{C}$ and $\mathrm{N}$ was based on harvested stalks as the other structures remained in the field as straw.

\section{Biomass, intercepted radiation and auxiliary estimates}

There were four subplots (2-m length) per experimental plot used to count the stalks number (SN). The stalks height $(\mathrm{SH}, \mathrm{cm})$ was recorded in three replicates per subplot (12 replicates per experimental plot), with measurements taken from the soil surface to the visible dewlap of the first fully expanded leaf. In addition, five plants per experimental plot were sampled, weighed, fractionated into fully expanded leaves, sheaths, dead leaves and sheaths, emerging leaves, and stalks, and then the fresh biomass was obtained. The internode number (IN, units), length (IL, $\mathrm{cm}$ ), and width (IW, $\mathrm{mm}$ ) were recorded from soil surface to top canopy position (bottom-up). Then, all samples were dried in a forcedair circulation oven $\left(60^{\circ} \mathrm{C}\right)$ until constant mass was reached. Fully expanded leaves, sheaths, dead leaves and sheaths, emerging leaves, and pseudostalks were considered as straw (crop residue subject to post-harvest deposition) and subdivided into leaf structures (leaf dry biomass-LDB, sheath dry biomass-SDB, and dead leaf and sheath dry biomassDLSDB) and pointers (emerging leaf dry biomass-ELDB and pseudostalk dry biomass-PSDB). The sum of the dry mass of previous cited structures resulted in the total dry biomass (TDBAP). All biometric and biomass procedures followed Silva et al. (2012 b; 2014 b). The relationships between SN and SH and accumulated degree days (ADD, ${ }^{\circ} \mathrm{C}$ day) were fitted. The ADD was based on the temperature data registered by the weather station and calculated according to the equation: $\mathrm{ADD}=\left[\left(\mathrm{t}_{\max }+\mathrm{t}_{\min }\right) / 2-\mathrm{t}_{\mathrm{b}}\right)$, where $\mathrm{t}_{\max }$ and $\mathrm{t}_{\min }$ are the maximum and minimum air temperatures, respectively $\left({ }^{\circ} \mathrm{C}\right)$, and $\mathrm{t}_{\mathrm{b}}$ is the basal temperature $\left(10^{\circ} \mathrm{C}\right)$ (Sinclair et al. 2004). Biomass partitioning, stalk height growth (SHS, $\mathrm{cm}$ ), and internode volume (VI, $\mathrm{cm}^{3}$ ) were estimated (Sinclair et al. 2004; 2005; Singels et al. 2005). Before harvesting, crop lodging was measured from the count of lodging plants in three replicates per subplot (12 replicates per experimental plot) (Carlin et al. 2008).

Photosynthetically active radiation above $\left(\mathrm{PAR}_{\mathrm{A}}\right)$ and below $\left(\mathrm{PAR}_{\mathrm{B}}\right)$ the canopy was measured from a previously calibrated ceptometer (AccuPAR-L80, Decagon Devices Inc., Pullman WA, USA). Measurements with the ceptometer were taken between 11:00 and 13:00 h, with four measurements above and four below the sugarcane canopy in an alternating manner so that the instrument covered half the crop row. The readings were made in ten subplots, always in the same positions, under clear sky conditions (Silva et al. 2012 b; 2014 b). By means of the difference between $P_{A R_{A}}$ and $P_{A}$, the intercepted PAR fraction (fPAR, dimensionless) was calculated (Singels et al. 2005). 


\section{Industrial yield and juice quality indicators}

Sugarcane yield was measured in tons of stalks per hectare (TSH, $\left.\mathrm{Mg} \cdot \mathrm{ha}^{-1}\right)$, from extrapolation of the average weight of 20 subplots of $35.2 \mathrm{~m}^{2}$ per experimental plot, sampled before the final crop harvest. Subsamples of stalks were used for evaluation of juice quality, such as raw sugar percentage (SRP, \%), total reducing sugars (TRS, \%), total soluble solids ( ${ }^{\circ} \mathrm{Brix}$ ), purity (\%), fiber content (\%) and sucrose percentage of the juice (Pol, \%), and estimates of crude sugar yield (CSY, Mg $\cdot \mathrm{ha}^{-1}$ ) and crude alcohol yield (CALY, $\mathrm{m}^{3} \cdot \mathrm{ha}^{-1}$ ) (Silva et al. $2014 \mathrm{~b}$ ).

\section{Crop water productivity}

Crop water productivity (CWP) was calculated on the basis of dry biomass, TSH, CSY, carbon, and nitrogen and obtained from the ratio between TDBAP, LDB, SDB, DLSDB, TSH, CALY or CSY, and cumulative evapotranspiration during the cycle ( $\Sigma$ ET) (Silva et al. $2011 \mathrm{a}$ ). The CWP for carbon and nitrogen $\left(\mathrm{kg} \cdot \mathrm{ha}^{-1} \cdot \mathrm{mm}^{-1}\right)$ was based on the product of CWP and the carbon and nitrogen content ( $\mathrm{w}, \mathrm{g} \cdot \mathrm{kg}^{-1}$ ) (Silva et al. $2014 \mathrm{~b}$ ). The $\Sigma \mathrm{ET}$ was computed from application of the energy balance method (Bowen's ratio), with micrometeorological data collected in towers installed inside the experimental area. The latent heat flux $(\lambda \mathrm{E})$ was calculated according to Silva et al. (2011 b) and analyzed by applying the criteria defined by Perez et al. (1999). According to the recommendations of these authors, the physical consistency of hourly meteorological data was evaluated, based on data from the water vapor pressure profile, sensor resolution, and signals from the temperature and water vapor pressure gradients. The towers $(7 \mathrm{~m})$ were used for monitoring the temperature and relative humidity (HMP155A, Vaisala Inc., Helsinki, Finland) at two levels above the crop (0.50 and $2.0 \mathrm{~m}$ ), radiation balance (RN-Lite, Kipp and Zonen, Delft, the Netherlands) at $6.8 \mathrm{~m}$ from the soil surface, and soil heat flow (HFP01SC Soil Heat Flux Plate, Hukseflux, Delft, the Netherlands) at $0.05 \mathrm{~m}$ depth adjacent to the crop row. All sensors in each tower were connected to a datalogger (CR1000, Campbell Scientific, Logan UT, USA), taking readings every $60 \mathrm{~s}$ and recording the average every $10 \mathrm{~min}$.

\section{Data analysis and statistical procedures}

Fischer's parametric test $(\mathrm{p}<0.05)$ was used to evaluate the effects of keeping straw on sugarcane growth (12 replicates) and development (10 subplots), total mass on a dry basis per sugarcane structural part (5 replicates), yield (20 subplots), and juice quality (20 subplots). All statistical procedures were performed using XLSTAT v. 2017 software (Addinsoft, Boston MA, USA, www.xlstat.com). Adjustments of mathematical models, such as sigmoid, Gaussian, exponential, and linear, were performed, with the significance of the models and of their parameters evaluated using F and Student's t-tests $(\mathrm{p}<0.05)$.

\section{RESULTS}

\section{Straw decomposition and releases of carbon and nitrogen}

The average straw decomposition rate was $0.0608 \mathrm{Mg} \cdot \mathrm{ha}^{-1} \cdot \mathrm{day}^{-1}$. At the end of the cycle (342 days), the remaining dry mass was $6.4 \mathrm{Mg} \cdot \mathrm{ha}^{-1}$ (Fig. 1). However, an increase from 5.0 to $8.2 \mathrm{Mg} \cdot \mathrm{ha}^{-1}$ in dry mass above the soil occurred from 258 to 307 days, and this was due to the deposition of new leaves. Therefore, the total decomposition was $76 \%$, considering the initial amount of straw $\left(27.2 \mathrm{Mg} \cdot \mathrm{ha}^{-1}\right)$, the deposition of new leaves $\left(3.2 \mathrm{Mg}^{\circ} \mathrm{ha}^{-1}\right)$, and the remaining dry mass $\left(6.4 \mathrm{Mg} \cdot \mathrm{ha}^{-1}\right)$. The time related to the increase in straw dry biomass (tnsd) can be estimated as tnsd $=1.2642 / \mathrm{k}$, where $k$ is the decomposition constant, in days ${ }^{-1}$. The straw carbon concentration at the beginning of the cycle was $470 \mathrm{~g} \mathrm{C}^{\mathrm{kg}} \mathrm{kg}^{-1}$, reaching $440 \mathrm{~g} \mathrm{C} \mathrm{kg}^{-1}$ at the end. On the other hand, the straw nitrogen concentration was higher at the end of the cycle $\left(7.4 \mathrm{~g} \mathrm{~N} \cdot \mathrm{kg}^{-1}\right)$ when compared to the beginning $\left(4.1 \mathrm{~g} \mathrm{~N} \cdot \mathrm{kg}^{-1}\right)$. The decomposed straw $\left(20.8 \mathrm{Mg} \cdot \mathrm{ha}^{-1}\right)$ promoted the release of $10.2 \mathrm{Mg} \mathrm{C} \cdot \mathrm{ha}^{-1}$ and 


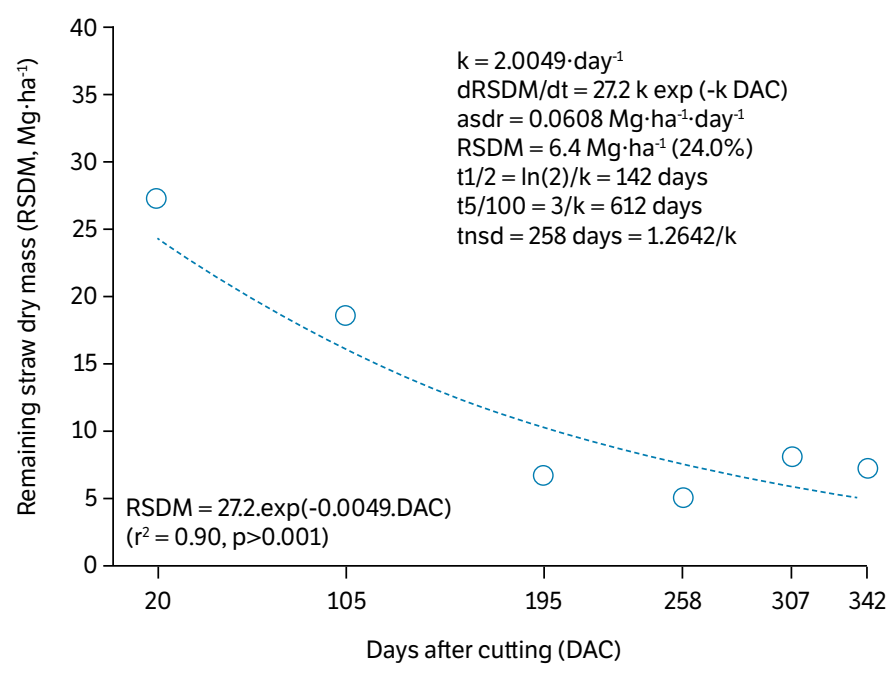

Figure 1. Dry mass of the remaining straw over time, decomposition rate $(k)$, remaining dry mass, half-life $(1 / 2)$, $95 \%$ decomposition time $(\mathrm{t} 5 / 100)$ and time of new straw deposition (tnsd). Vertical lines indicate standard error of estimate $(n=4)$.

$63.1 \mathrm{~kg} \mathrm{~N} \cdot \mathrm{ha}^{-1}$ during 342 days of crop cycle, representing 78 and $57 \%$ of the initial amounts, respectively $\left(13.0 \mathrm{Mg} \mathrm{C} \cdot \mathrm{ha}^{-1}\right.$ and $\left.110.6 \mathrm{~kg} \mathrm{~N} \cdot \mathrm{ha}^{-1}\right)$.

\section{Sugarcane growth and development}

The number of stalks per area was not affected when covering soil surface with straw ( $p=0.076$, Fig. 2a), but it was 2.6 stalks per $\mathrm{m}^{2}$ on average higher in no-straw cultivation. The stalk height was decreased $(p=0.014)$ by straw, with an average difference of $0.38 \mathrm{~m}$ between stalks of the two cropping systems (Fig. 2b). Plant height affects crop lodging, and this phenomenon was noticed earlier when soil was not covered by straw (Fig. 3a). In Fig. 3b, the data shows that there was no effect on the IN, but in Fig. 3c, it is possible to see that the largest individual volumes occurred between the $3^{\text {rd }}$ and $14^{\text {th }}$ positions on the stalk. It was also observed that the volumes up to the sixth position in the straw crop were lower than in the no-straw treatment, although there was no significant difference in the first three positions. At the end of the cycle, straw did not affect the total stalk volume ( $p=0.522$, Fig. 3c). Sugarcane development was also delayed in the with-straw treatment even with the air temperature being higher than in the no-straw treatment $\left(0.7^{\circ} \mathrm{C}\right)$. Sugarcane plants took $248^{\circ} \mathrm{C}$ day more to reach $80 \%$ soil cover (Fig. $\left.4 \mathrm{a}\right)$.

\section{Yield, juice quality indicators and $\mathrm{C}$ and $\mathrm{N}$ release/export by the sugarcane harvest}

The final biomass partitioning for the stalks was similar between treatments ( $80 \%$ in the no-straw treatment vs. $78 \%$ in the straw treatment). Neither the total dry biomass nor the stalk yield was affected by straw deposition ( $p=0.229$, Fig. $4 \mathrm{~b}$; Table 1$)$. Only purity and fiber content were increased when straw was used to cover soil surface (Table 1). While the amount of carbon accumulated by plants was not affected by straw maintenance, the amount of $\mathrm{N}$ extracted was ( $p=0.014$, Table 1$)$. Carbon and $\mathrm{N}$ release/export was significantly higher in the with-straw treatment $(p=0.008$, Table 1$)$.

\section{Crop water productivity}

Soil cover decreased overall evapotranspiration by $25 \%$ (whole cycle), resulting in a $26 \%$ increase in CWP on TDBAP basis (Table 2). When considering TSH, sugar, and alcohol yields, CWP was even higher (28, 38, and 37\%, respectively). 
(a)

Days after cutting (DAC)

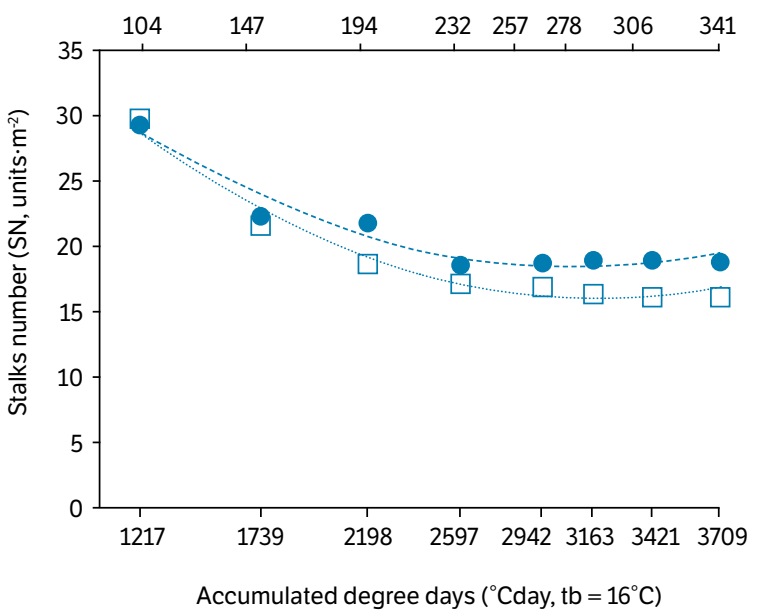

(b)

Days after cutting (DAC)

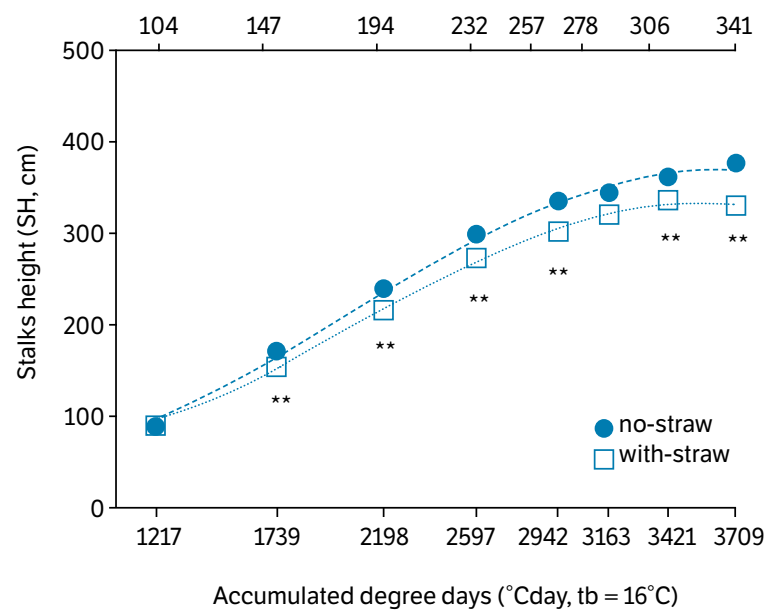

Figure 2. Number (a) and height (b) of millable stalks of sugarcane under straw management in the Brazilian semiarid region. ${ }^{\star \star}$ indicates significant difference by Fischer's parametric test $(p<0.05)$.

(a)

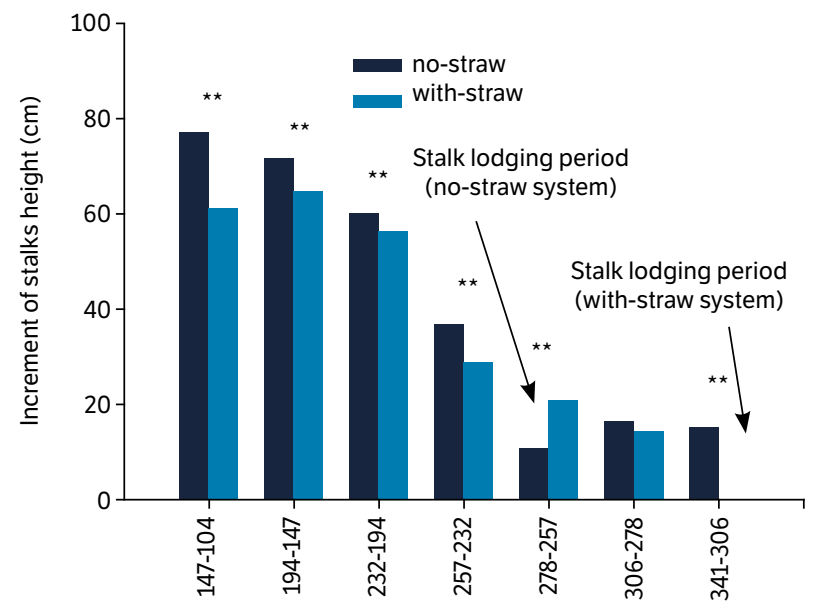

Interval between days after cutting

(c)

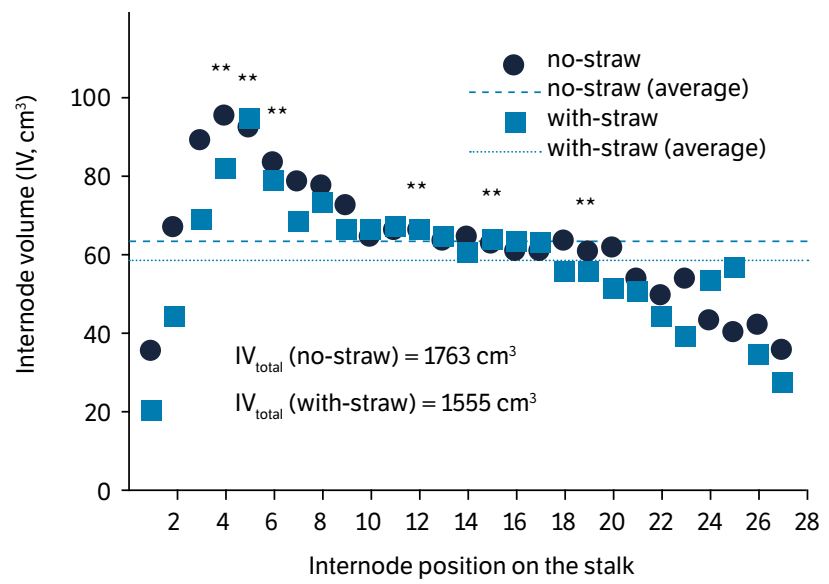

Figure 3. (a) Increment in height, (b) internode number per stalk over time and (c) internode volume in relation to its position, from bottom-up, on the stalk of sugarcane under straw management in the Brazilian semiarid region. ${ }^{\star \star}$ indicates significant difference by Fischer's parametric test $(p<0.05)$. 
(a)

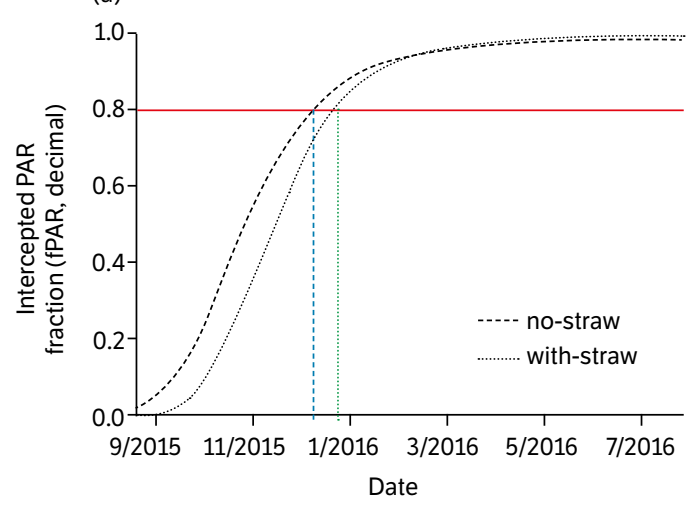

(b)

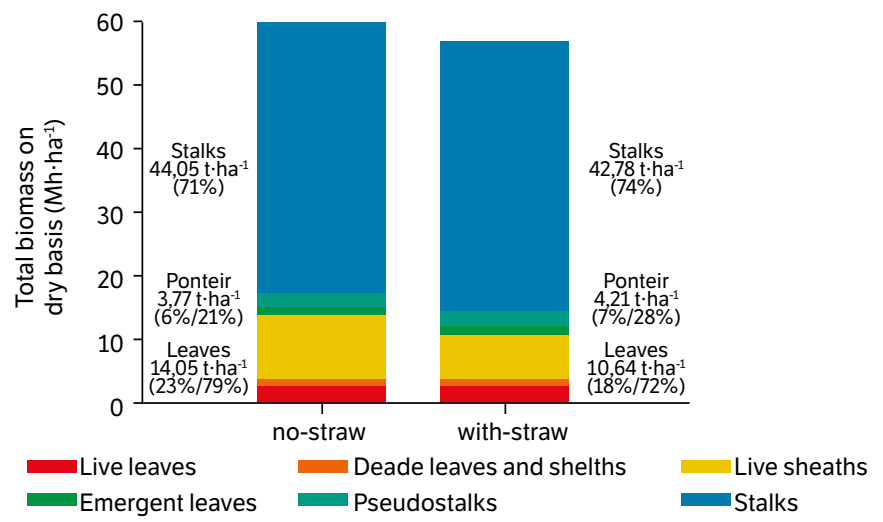

Figure 4. (a) Plant cover index (b) and total mass on a dry basis per sugarcane structural part under straw management in the Brazilian semiarid region.

Table 1. Industrial yield, juice quality indicators and carbon and nitrogen extraction/exports at harvest to the 341 days after cutting of sugarcane under straw management in the Brazilian semiarid.

\begin{tabular}{|c|c|c|c|c|c|c|c|c|c|c|c|c|c|}
\hline \multirow{2}{*}{ Crop } & \multirow{2}{*}{ TSH } & \multirow{2}{*}{ Brix } & \multirow{2}{*}{ Purity } & \multirow{2}{*}{ Fiber } & \multirow{2}{*}{ SRP } & \multirow{2}{*}{ TRS } & \multirow{2}{*}{ Pol } & \multirow{2}{*}{ CSY } & \multirow{2}{*}{ CALY } & \multicolumn{2}{|c|}{ Extraction } & \multicolumn{2}{|c|}{ Export } \\
\hline & & & & & & & & & & C & $\mathbf{N}$ & C & $\mathbf{N}$ \\
\hline & Mg $\cdot h a^{-1}$ & $\circ$ & $\%$ & $\%$ & $\%$ & Mg $\cdot h a^{-1}$ & $\%$ & Mg $\cdot h a^{-1}$ & $\mathrm{~m}^{3} \cdot \mathrm{ha}^{-1}$ & Mg $\cdot h a^{-1}$ & $\mathbf{k g} \cdot \mathrm{ha}^{-1}$ & Mg $\cdot h a^{-1}$ & $\mathbf{k g} \cdot \mathrm{ha}^{-1}$ \\
\hline No-straw & $166.76 a$ & $18.62 a$ & $85.67 b$ & $15.73 b$ & $12.65 a$ & $126.88 a$ & $15.97 a$ & $21.08 a$ & $15.12 a$ & $2.89 a$ & $8.92 b$ & $2.89 a^{\star}$ & $8.92 a^{*}$ \\
\hline With-straw & $160.16 a$ & $20.03 a$ & $85.90 a$ & $15.84 a$ & $13.62 a$ & $136.08 a$ & $17.21 a$ & $21.77 a$ & $15.56 a$ & $2.98 a$ & $10.50 a$ & $2.03 b^{\star \star}$ & $6.70 b^{\star \star}$ \\
\hline
\end{tabular}

Means in the vertical followed by the same letter are not different from each other at the $5 \%(\alpha<0.05)$ significance level by the Fisher's F parametric test (comparison between two samples), that is, there is no effect of the maintenance on the straw over the respective yield index. TSH: tons of stalk per hectare; SRP: sugar raw percentage; TRS: total reducing sugars; Pol: sucrose percentage in the juice; CSY: crude sugar yield; and, CALY: crude alcohol yield. * Exports from the harvesting of all the structures of the plant aerial part; ${ }^{\star \star}$ Exports only from harvesting the stalks.

Table 2. Crop water productivity (CWP) in basis on dry biomass, stalks per hectare, sugar crude yield, carbon and nitrogen, under straw management in the Brazilian semiarid.

\begin{tabular}{|c|c|c|c|c|c|c|c|c|c|c|}
\hline \multirow[b]{2}{*}{ Crop } & $\mathrm{CWP}_{\text {TDBAP }}$ & $\mathrm{CWP}_{\text {Leaves }}$ & $\mathrm{CWP}_{\text {Pointer }}$ & $\mathrm{CWP}_{\text {straw }}$ & $\mathrm{CWP}_{\text {Stalks }}$ & $\mathrm{CWP}_{\mathrm{TSH}}$ & $\mathrm{CWP}_{\mathrm{CSY}}$ & \multirow{2}{*}{$\begin{array}{c}\mathrm{CWP}_{\text {CALY }} \\
\mathrm{L} \cdot \\
\mathrm{ha}^{-1} \cdot \mathrm{mm}^{-1}\end{array}$} & \multirow{2}{*}{$\begin{array}{c}\mathrm{CWP}_{\mathrm{c}} \\
\mathrm{kgN} \cdot \\
\mathrm{ha}^{-1} \cdot \mathrm{mm}^{-1}\end{array}$} & \multirow{2}{*}{$\begin{array}{c}\mathrm{CWP}_{\mathrm{N}} \\
\begin{array}{c}\mathrm{gN} \cdot \\
\mathrm{ha}^{-1} \cdot \mathrm{mm}^{-1}\end{array}\end{array}$} \\
\hline & & & & $\mathrm{kg} \cdot \mathrm{ha} \mathrm{a}^{-1} \cdot \mathrm{mm}^{-1}$ & & & & & & \\
\hline No-straw & $38.24 b$ & $8.83 a$ & $2.37 \mathrm{~b}$ & $11.20 \mathrm{~b}$ & $27.04 b$ & $104.75 b$ & $13.24 \mathrm{~b}$ & $9.50 \mathrm{~b}$ & $1.82 \mathrm{~b}$ & $5.60 \mathrm{~b}$ \\
\hline With-straw & $48.26 a$ & 8.91a & $3.53 a$ & $12.44 a$ & $35.82 a$ & 134.13a & $18.24 a$ & $13.03 a$ & $2.50 a$ & $8.79 a$ \\
\hline
\end{tabular}

Means in the vertical followed by the same letter do not differ from each other at the significance level of $5 \%(\alpha<0.05)$ by the F parametric test of Fisher (comparison between two samples). TDBAP: total dry biomass of the aerial part; Leaves: dry biomass of leaf and sheaths, both live and dead; Pointer: dry biomass of pseudostalk and emergent leaves; Straw: Leaves and pointer; TSH: tones of stalks per hectare; CSY: sugar crude yield; CALY: alcohol crude yield; C: carbon and N: nitrogen.

Crop water productivity on TSH basis reached $134.13 \mathrm{~kg} \cdot \mathrm{ha}^{-1} \cdot \mathrm{mm}^{-1}$ when straw was covering the soil. The straw also increased CWP on carbon $(+26 \%)$ and nitrogen $(+111 \%)$ bases $(\mathrm{p}=0.043$, Table 2$)$.

\section{DISCUSSION}

The decomposition constant $(k)$ of 0.0049 day $^{-1}$ - equivalent to an average decomposition rate of $0.0608 \mathrm{Mg} \cdot \mathrm{ha}^{-1} \cdot \mathrm{day}^{-1}-$ can be considered high (Fig. 1) when compared to Pimentel et al. (2019), who found values of $k$ from 0.0021 to 0.0041 day $^{-1}$ using 3.5 and $14.0 \mathrm{Mg} \cdot \mathrm{ha}^{-1}$ of straw in the field, as well as Sousa Junior et al. (2018), who observed values of $k$ of 0.0012 and 0.0026 day $^{-1}$ using 3.5 and $21.0 \mathrm{Mg} \mathrm{ha}^{-1}$, respectively. The value of $k$ depends on straw quantity, composition, and management, 
microbial activity, and environmental conditions (Fortes et al. 2012; Pimentel et al. 2019; Sousa Junior et al. 2018), and the hot Brazilian semiarid region favors the decomposition rate in irrigated fields (Thongjoo et al. 2005; Zhou et al. 2016). The decomposition of $76 \%$ of the straw during the experiment can also be considered high when compared to studies conducted in other regions (Fortes et al. 2012; Pimentel et al. 2019; Vitti et al. 2008). Still, it seems to be related to a high C:N ratio (118) at the beginning of crop cycle, which hinders mineralization of the nutrients within the biomass. The remaining

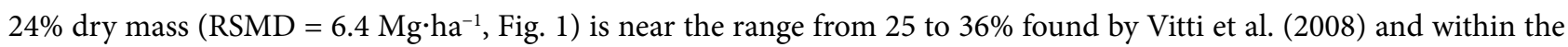
range from 8 to $49 \%$ found by Pimentel et al. (2019), who used $9.0 \mathrm{Mg}^{\circ} \mathrm{ha}^{-1}$ and 3.5 to $14.0 \mathrm{Mg} \cdot \mathrm{ha}^{-1}$, respectively, on the soil surface under subtropical conditions in Southern Brazil.

The higher decomposition rates are expected to affect the following crop cycles since the half-life of the remaining dry mass ( $\mathrm{t} 1 / 2)$ was 142 days and the time for decomposition of $95 \%$ of the initial straw ( $\mathrm{t} 5 / 100)$ would be 612 days, above the 342 -day cycle duration of this study. Even with the high values of $k\left(0.0049 \mathrm{day}^{-1}\right)$ and total decomposition (76\%), the great values of $\mathrm{t} 1 / 2$ and $\mathrm{t} 5 / 100$ are indicative that keeping $27.2 \mathrm{Mg} \cdot \mathrm{ha}^{-1}$ of sugarcane straw on the soil surface at each harvest can be considered excessive even for the irrigated and hot environment where the experiment was conducted. So, a maximum of $20.8 \mathrm{Mg} \cdot \mathrm{ha}^{-1}$ (27.2 minus $6.4 \mathrm{Mg} \cdot \mathrm{ha}^{-1}$ ) can be kept on the soil surface to minimize accumulation for the subsequent cycle. Keeping sugarcane straw in excessive quantities might impair the following cycle. In Southern Brazil, where the climate is classified as tropical-humid, Sousa Junior et al. (2018) stated that t1/2 depends directly on the straw amount and the $k$-value $\left(560,402,259\right.$, and 262 days for $3.5,7.0,14.0$, and $21.0 \mathrm{Mg} \cdot \mathrm{ha}^{-1}$ and $k$-value equal to $0.0012,0.0017,0.0027$, and 0.0026 , respectively).

The benefits of keeping sugarcane straw varies according to climate conditions and sugarcane-harvesting season (Aquino et al. 2018; Lisboa et al. 2018). In the relatively colder Southern Brazil (subtropical climate, states of São Paulo and

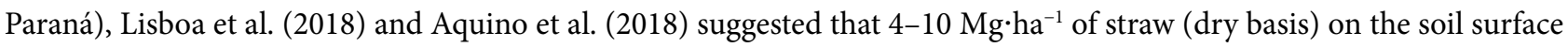
would be required to sustain crop yield long-term without any negative effect on the sugarcane development.

Carbon release rates were greater than $\mathrm{N}$ mineralization rates, as the C:N ratio was reduced by $59 \%$ during the experiment. This trend was verified by Vitti et al. (2008), Pimentel et al. (2019) and Sousa Junior et al. (2018). According to these authors, the presence of sugarcane straw can increase $\mathrm{C}$ and $\mathrm{N}$ stocks within the surface soil layer. On the other hand, complete sugarcane straw removal depletes soil C stocks and reduces $\mathrm{N}$ cycling in sugarcane fields.

The lower initial growth of the sugarcane promoted by keeping straw is due to the physical barrier imposed, but it may also be associated with lower soil temperature, which reduces plant growth (Awe et al. 2015; Ramburan and Nxumalo 2017; Sandhu et al. 2013; Vianna et al. 2020). In agreement with results found in this paper, Ramburan and Nxumalo (2017) found reductions in the number and height of stalks due to keeping straw, regardless the region in South Africa, the cultivar, and the season of the beginning of the cycle (summer or winter). Higher VI occurred between the $3^{\text {rd }}$ and $14^{\text {th }}$ positions (Fig. 3c), quite similar to those observed by Silva et al. (2012 b), who found higher magnitudes between the $2^{\text {nd }}$ and $17^{\text {th }}$ positions for the cultivar RB 92-579.

It was observed that volumes up to the $6^{\text {th }}$ position in the straw crop were lower than in the no-straw treatment. This result indicates that sugarcane presented initial growth limitation because of keeping the straw, which was not observed in other variables of the stalks since their measurements were initiated only on day 104 (Figs. 3a, 3b, and 4b). Thus, the individual VI up to the $6^{\text {th }}$ position can be considered a good indicator of the effect of straw on sugarcane growth even if their measurements are obtained only at harvest. However, measurement of biometric variables over time allows us to indicate when the crop overcomes the physical obstacle promoted by straw. I was observed that sugarcane development was slower in the withstraw treatment $\left(248^{\circ} \mathrm{C}\right.$ day more to reach $80 \%$ ground cover, Fig. 4 a). This result is similar to that mentioned by Olivier and Singels (2015) and Carvalho et al. (2019), who verified a reduction in sugarcane development rate because of keeping straw in the climatic conditions of South Africa and Brazil, respectively.

Crop lodging is a phenomenon common in sugarcane cultivation without straw. Carlin et al. (2008) observed that lodging increases IL and IN and the yield of sugarcane cultivars (IAC86-2210 and SP80-184) but promotes bud sprouting (thicker stalks and larger and shorter leaves), which reduces the quality of the raw matter due to the decreased content of sucrose and the high content of reducing sugars (Berding and Hurney 2005). Thus, maintaining the straw in the field may also help to reduce crop lodging. 
Straw did not affect the stalk yield ( $\mathrm{p}>0.05$, Table 1), as observed by Olivier and Singels (2015), Souza et al. (2005), and Olivier and Singels (2012). The last observed reductions were of 4 and 15\% in the cycle of plant cane and ratoon, respectively. The presence of straw on the soil increased the juice purity, and the remaining other industrial indexes were not negatively affected by the straw (Table 1), as found by Ramburan and Nxumalo (2017), Nxumalo et al. (2017), and Aquino et al. (2018).

The $\mathrm{N}$ content was $18 \%$ greater in the with-straw treatment than in the no-straw treatment because of the benefit of $\mathrm{N}$ and $\mathrm{C}$ release from the decomposed straw and improvement of the thermal and water regime of the soil that favors crop development and soil microbial activity (Awe et al. 2015; Fortes et al. 2012). In the no-straw treatment, $\mathrm{C}$ and N fixed by the plant throughout the cycle are released at harvest, while in the straw treatment, $26 \%$ of the $\mathrm{C}$ and $53 \%$ of the $\mathrm{N}$ is kept within the area of cultivation (Table 1). Fixation of these elements over time compensates for the partial negative effects on initial crop growth promoted by straw. However, not all $\mathrm{N}$ applied in fertilization $\left(420 \mathrm{~kg} \cdot \mathrm{ha}^{-1}\right)$ or released by straw decomposition $\left(63.1 \mathrm{~kg} \mathrm{~N} \cdot \mathrm{ha}^{-1}\right)$ was available to the plant, because the microorganisms present in the soil immobilized $\mathrm{N}$ for its own use, as a consequence of high C:N (118) (Pimentel et al. 2019).

The CWP depends on the cultivar, the water management practice adopted, and the crop cycle (plant cane or ratoon) (Olivier and Singels 2015; Silva et al. 2012 a), but it is strongly affected by the maintenance of straw in the field. It was observed that CWP increased due to the reduction of evaporation promoted by straw (25\%) and the small biomass change (-5.3\% in comparison to the no-straw treatment, Table 2), as observed by Bu et al. (2013), Olivier and Singels (2015), and Yan et al. (2017). In terms of TSH, the CWP for straw cultivation obtained was $134.13 \mathrm{~kg} \cdot \mathrm{ha}^{-1} \cdot \mathrm{mm}^{-1}$, a value higher than that reported by Olivier and Singels (2012), Silva et al. (2011 a) and Nassif et al. (2019). The straw also increased the CWP and $\mathrm{CWP}_{\mathrm{N}}$ by the crop, as a result of the reduction in evapotranspiration and the increase in carbon stock and nitrogen extraction by the crop, which in turn might be associated with the improvement of soil microbial activity (Kader et al. 2017).

\section{CONCLUSION}

It was investigated the effect of straw management on the growth, yield, and CWP of sugarcane cultivated in an irrigated tropical semiarid environment. Although the straw presented a high decomposition rate in the semiarid environment, it was suggested keeping no more than $20.8 \mathrm{Mg} \cdot \mathrm{ha}^{-1}$ of straw on soil surface. Growth and development of the crop were affected through the first 100 days of the cycle, with a reduction in stalk height and lower crop development rate.

Keeping sugarcane straw on the soil surface may also help to reduce crop lodging. Most of the industrial indexes regarding juice quality are not negatively affected by the presence of straw. The carbon and nitrogen fixation released by decomposed straw over time compensates the slower rates of initial crop growth by keeping straw. The straw increases the $\mathrm{N}$ extraction and $\mathrm{N}$ and $\mathrm{C}$ cycling in the field. Crop water productivity increased in terms of dry biomass, stalks yield, crude sugar, ethanol, carbon, and nitrogen.

\section{FUNDERS}

Conselho Nacional de Desenvolvimento Científico e Tecnológico

Grants Nos.: 401662/2016, 403946/2013, 301424/2015, 305286/2015-3, 305286/2015-3, 300916/2018, 152251/2018-9 and 309421/2018-7),

Fundação de Amparo à Ciência e Tecnologia de Pernambuco

Grant No.: APQ-1159-1.07/14

Fundação de Amparo à Pesquisa do Estado de São Paulo

Grants Nos.: 2017/20925-0, 2017/50445-0)

Coordenação de Aperfeiçoamento de Pessoal de Nível Superior 


\section{AUTHOR'S CONTRIBUTION}

Conceptualization: Marin F. R. and Silva T. G. F.; Methodology: Marin F. R. and Silva T. G. F.; Investigation: Souza C. A. A., Souza L. S. B. and Moura M. S. B.; Writing - Original Draft: Souza C. A. A., Souza L. S. B. and Moura M. S. B.; Writing: Marin F. R. and Silva T. G. F.; Funding Acquisition: Marin F. R. and Silva T. G. F.; Resources: Souza L. S. B. and Moura M. S. B.; Supervision: Marin F. R. and Silva T. G. F.

\section{REFERENCES}

[Embrapa] Empresa Brasileira de Pesquisa Agropecuária. (2013). Sistema brasileiro de classificação de solos. Brasília: Embrapa. [Accessed Sept. 29, 2020]. Available at: http://livimagens.sct.embrapa.br/amostras/00053080.pdf

[IBGE] Instituto Brasileiro de Geografia e Estatística. (2019). Índice nacional de preços ao consumidor amplo 15. [Accessed Jan. 28 , 2019]. Available at: https://sidra.ibge.gov.br/home/ipca15/brasil

Allen, R. G., Pereira, L. S., Raes, D. and Smith, M. (1998). Crop evapotranspiration - Guidelines for computing crop water requirements - FAO Irrigation and drainage paper 56. Roma: FAO. [Accessed Sept. 29, 2020]. Available at: https://www.scscourt.org/complexcivil/105CV049053/ volume3/172618e_5xAGWAx8.pdf

Aquino, G. S., Medina, C. C., Silvestre, D. A., Gomes, E. C., Cunha, A. C. B., Kussaba, D. A. O., Almeida, L. F., Shahab, M. and Santiago, A. D. (2018). Straw removal of sugarcane from soil and its impacts on yield and industrial quality ratoons. Scientia Agricola, 75, 526-529. https://doi.org/10.1590/1678-992x-2017-0093

Awe, G. O., Reichert, J. M. and Wendroth, O. O. (2015). Temporal variability and covariance structures of soil temperature in a sugarcane field under different management practices in southern Brazil. Soil and Tillage Research, 150, 93-106. https://doi.org/10.1016/j.still.2015.01.013

Berding, N. and Hurney, A. P. (2005). Flowering and lodging, physiological-based traits affecting cane and sugar yield: What do we know of their control mechanisms and how do we manage them? Field Crops Research, 92, 261-275. https://doi.org/10.1016/j.fcr.2005.01.015

Bu, L.-D., Liu, J.-L., Zhu, L., Luo, S.-S., Chen, X.-P., Li, S.-Q., Hill, R. L. and Zhao, Y. (2013). The effects of mulching on maize growth, yield and water use in a semi-arid region. Agricultural Water Management, 123, 71-78. https://doi.org/10.1016/j.agwat.2013.03.015

Carlin, S. D., Silva, M. A. and Rossetto, R. (2008). Parâmetros biométricos e produtividade da cana-de-açúcar após tombamento dos colmos. Bragantia, 67, 845-853. https://doi.org/10.1590/S0006-87052008000400006

Carvalho, K. S., Vianna, M. S., Nassif, D. S. P., Costa, L. G., Folegatti, M. V. and Marin, F. R. (2019). Effect of soil straw cover on evaporation, transpiration and evapotranspiration in sugarcane cultivation. Australian Journal of Crop Science, 13, 1362-1368. https://doi.org/10.21475/ ajcs.19.13.08.p1814

Costa, L. G., Marin, F. R., Nassif, D. S. P., Pinto, H. M. S. and Lopes-Assad, M. L. R. C. (2014). Simulação do efeito do manejo da palha e do nitrogênio na produtividade da cana-de-açúcar. Revista Brasileira de Engenharia Agrícola e Ambiental, 18, 469-474. https://doi. org/10.1590/S1415-43662014000500001

Fortes, C., Trivelin, P. C. O. and Vitti, A. C. (2012). Long-term decomposition of sugarcane harvest residues in Sao Paulo state, Brazil. Biomass and Bioenergy, 42, 189-198. https://doi.org/10.1016/j.biombioe.2012.03.011

$\mathrm{Hu}, \mathrm{J}$., Wu, J. and Qu, X. (2018). Decomposition characteristics of organic materials and their effects on labile and recalcitrant organic carbon fractions in a semi-arid soil under plastic mulch and drip irrigation. Journal of Arid Land, 10, 115-128. https://doi.org/10.1007/s40333-017-0035-1

Kader, M. A., Senge, M., Mojid, M. A. and Ito, K. (2017). Recent advances in mulching materials and methods for modifying soil environment. Soil and Tillage Research, 168, 155-166. https://doi.org/10.1016/j.still.2017.01.001 
Lisboa, I. P., Cherubin, M. R., Lima, R. P., Cerri, C. C., Satiro, L. S., Wienhold, B. J., Schmer, M. R., Jin, V. L. and Cerri, C. E. P. (2018). Sugarcane straw removal effects on plant growth and stalk yield. Industrial Crops \& Products, 111, 794-806. https://doi.org/10.1016/j. indcrop.2017.11.049

Marin, F. R. and Jones, J. W. (2014). Process-based simple model for simulating sugarcane growth and production. Scientia Agricola, 71, 1-16. https://doi.org/10.1590/S0103-90162014000100001

Marin, F. R., Thorburn, P. J., Costa, L. G. and Otto, R. (2014). Simulating long-term effects of trash management on sugarcane yield for Brazilian cropping systems. Sugar Tech, 16, 164-173. https://doi.org/10.1007/s12355-013-0265-2

Marin, F. R., Inman-Bamber, G., Silva, T. G. F., Vianna, M. S., Nassif, D. S. P. and Carvalho, K. S. (2020). Sugarcane evapotranspiration and irrigation requirements in tropical climates. Theoretical and Applied Climatology, 140, 1349-1357 https://doi.org/10.1007/s00704-020-03161-z

Moura, M. S. B., Galvincio, J. D., Brito, L. T. L., Souza, L. S. B., Sá, I. I. S. and Silva, T. G. F. (2007). Clima e água de chuva no Semi-Árido. In L. T. L. Brito, M. S. B. Moura and G. F. B. Gama (Eds.), Potencialidades da água de chuva no semi-árido brasileiro (p. 37-59). Petrolina: Embrapa. [Accessed Sept. 29, 2020]. Available at: https://ainfo.cnptia.embrapa.br/digital/bitstream/CPATSA/36534/1/OPB1515.pdf

Nassif, D. S. P., Costa, L. G., Vianna, M. S., Carvalho, K. S. and Marin, F. R. (2019). The role of decoupling factor on sugarcane crop water use under tropical conditions. Experimental Agriculture, 55, 913-923. https://doi.org/10.1017/S0014479718000480

Nxumalo, N., Ramburan, S. and Steyn, J. M. (2017). Growth and yield responses of commercial sugarcane cultivars to mulching in the coastal rainfed region of South Africa. South African Journal of Plant and Soil, 34, 9-18. https://doi.org/10.1080/02571862.2016.1148787

Olivier, F. C. and Singels, A. (2012). The effect of crop residue layers on evapotranspiration, growth and yield of irrigated sugarcane. Water SA, 38, 77-86. https://doi.org/10.4314/wsa.v38i1.10

Olivier, F. C. and Singels, A. (2015). Increasing water use efficiency of irrigated sugarcane production in South Africa through better agronomic practices. Field Crops Research, 176, 87-98. https://doi.org/10.1016/j.fcr.2015.02.010

Perez, P. J., Castellvi, F., Ibañez, M. and Rosell, J. I. (1999). Assessment of reliability of Bowen ratio method for partitioning fluxes. Agricultural and Forest Meteorology, 97, 141-150. https://doi.org/10.1016/S0168-1923(99)00080-5

Pimentel, L. G., Cherubin, M. R., Oliveira, D. M. S., Cerri, C. E. P. and Cerri, C. C. (2019). Decomposition of sugarcane straw: Basis for management decisions for bioenergy production. Biomass and Bioenergy 122, 133-144. https://doi.org/10.1016/j.biombioe.2019.01.027

Ramburan, S. and Nxumalo, N. (2017). Regional, seasonal, cultivar and crop-year effects on sugarcane responses to residue mulching. Field Crops Research, 210, 136-146. https://doi.org/10.1016/j.fcr.2017.06.001

Sandhu, H. S., Gilbert, R. A., Kingston, G., Subiros, J. F., Morgan, K., Rice, R. W., Baucum, L., Shine Junior, J. M. and Davis, L. (2013). Effects of sugarcane harvest method on microclimate in Florida and Costa Rica. Agricultural and Forest Meteorology, 177, 101-109. https://doi. org/10.1016/j.agrformet.2013.04.011

Silva, D. J. and Queiroz, A. C. (2002). Análise de Alimentos: Métodos Químicos e Biológicos. Viçosa: UFV.

Silva, T. G. F., Moura, M. S. B., Zolnier, S, Soares, J. M., Vieira, V. J. S. and Gomes Júnior, W. F. (2011 a). Demanda hídrica e eficiência do uso de água da cana-de-açúcar irrigada no semiárido brasileiro. Revista Brasileira de Engenharia Agrícola e Ambiental, 15, $1257-1265$. https://doi.org/10.1590/S1415-43662011001200007

Silva, T. G. F., Moura, M. S. B., Zolnier, S., Soares, J. M., Souza, L. S. B. and Brandão, E. O. (2011 b). Variação do balanço de radiação e de energia da cana-de-açúcar irrigada no semiárido brasileiro. Revista Brasileira de Engenharia Agrícola e Ambiental, 15, 139-147. https:// doi.org/10.1590/S1415-43662011000200005

Silva, T. G. F., Moura, M. S. B., Zolnier, S., Carmo, J. F. A. and Souza, L. S. B. (2012 a). Biometria da parte aérea da cana soca irrigada no Submédio do Vale do São Francisco. Revista Ciência Agronômica, 43, 500-509. https://doi.org/10.1590/S1806-66902012000300012 
Silva, T. G. F., Moura, M. S. B., Zolnier, S., Soares, J. M., Vieira, V. J. S. and Júnior, W. G. F. (2012 b). Requerimento hídrico e coeficiente de cultura da cana-de-açúcar irrigada no semiárido brasileiro. Revista Brasileira de Engenharia Agrícola e Ambiental, 16, 64-71. https://doi. org/10.1590/S1415-43662012000100009

Silva, M. A., Arantes, M. T., Rhein, A. F. L., Gava, G. J. C. and Kolln, O. T. (2014 a). Potencial produtivo da cana-de-açúcar sob irrigação por gotejamento em função de variedades e ciclos. Revista Brasileira de Engenharia Agrícola e Ambiental, 18, 241-249. https://doi. org/10.1590/S1415-43662014000300001

Silva, T. G. F., Moura, M. S. B., Zolnier, S. and Souza, L. S. B. (2014 b). Biomassa seca acumulada, partições e rendimento industrial da cana-de-açúcar irrigada no Semiárido brasileiro. Revista Ceres, 61, 686-696. https://doi.org/10.1590/0034-737X201461050012

Silva, T. G. F., Souza, C. A. A., Moura, M. S. B., Marin, F. R., Carvalho, H. F. S., Leitão, M. M. V. B. R. and Galvíncio, J. D. (2019). Balanço de energia, emissão foliar e eficiência do uso da radiação pela cana-de-açúcar em cultivo sem e com palhada. Revista Brasileira de Meteorologia, 34, 69-78. https://doi.org/10.1590/0102-7786334016

Sinclair, T. R., Gilbert, R. A., Perdomo, R. E., Shine Junior, J. M., Powell, G. and Montes, G. (2004). Sugarcane leaf area development under field conditions in Florida, USA. Field Crops Research 88, 171-178. https://doi.org/10.1016/j.fcr.2003.12.005

Sinclair, T. R., Gilbert, R. A., Perdomo, R. E., Shine, J. M., Powell, G. and Montes, G. (2005). Volume of individual internodes of sugarcane stalks. Field Crops Research, 91, 207-215. https://doi.org/10.1016/j.fcr.2004.07.013

Singels, A., Smit, M. A., Redshaw, K. A. and Donaldson, R. A. (2005). The effect of crop start date, crop class and cultivar on sugarcane canopy development and radiation interception. Field Crops Research, 92, 249-260. https://doi.org/10.1016/j.fcr.2005.01.028

Sousa Junior, J. G. A., Cherubin, M. R., Oliveira, B. G., Cerri, C. E. P., Cerri, C. C. and Feigl, B. J. (2018). Three-year soil carbon and nitrogen responses to sugarcane straw management. BioEnergy Research, 11, 249-261. https://doi.org/10.1007/s12155-017-9892-X

Souza, Z. M., Prado, R. M., Paixão, A. C. S. and Cesarin, L. G. (2005). Sistemas de colheita e manejo da palhada de cana-de-açúcar. Pesquisa Agropecuária Brasileira, 40, 271-278. https://doi.org/10.1590/S0100-204X2005000300011

Teixeira, A. H. C. (2010). Determining regional actual evapotranspiration of irrigated crops and natural vegetation in the São Francisco River basin (Brazil) using remote sensing and Penman-Monteith equation. Remote Sensing, 2, 1287-1319. https://doi.org/10.3390/rs0251287

Teixeira, A. H. C., Scherer-Warren, M., Hernandez, F. B. T., Andrade, R. G. and Leivas, J. F. (2013). Large-scale water productivity assessments with MODIS images in a changing semi-arid environment: a Brazilian case study. Remote Sensing, 5, 5783-5804. https:// doi.org/10.3390/rs5115783

Thongjoo, C., Miyagawa, S. and Kawakubo, N. (2005). Effects of soil moisture and temperature on decomposition rates of some waste materials from agriculture and agro-industry. Plant Production Science, 8, 475-481. https://doi.org/10.1626/pps.8.475

Trivelin, P. C. O., Rodrigues, J. C. S. and Victoria, R. L. (1996). Utilization by early harvest sugar cane ratoon of the nitrogen from $15 \mathrm{~N}$-aqua ammonia and 15N-urea applied to the soil as vinasse N-complement. Pesquisa Agropecuária Brasileira, 31, 89-99.

Vianna, M. S., Nassif, D. S. P., Carvalho, K. S. and Marin, F. R. (2020). Modelling the trash blanket effect on sugarcane growth and water use. Computers and Electronics in Agriculture, 172, 105361. https://doi.org/10.1016/j.compag.2020.105361

Vitti, A. C., Trivelin, P. C. O., Cantarella, H., Franco, C. J., Faroni, C. E., Otto, R., Trivelin, M. O. and Tovajar, J. G. (2008). Mineralização da palhada e crescimento de raízes de cana-de-açúcar relacionados com a adubação nitrogenada de plantio. Revista Brasileira de Ciência do Solo, 32, 2757-2762. https://doi.org/10.1590/S0100-06832008000700020

Yan, Z., Gao, C., Ren, Y., Zong, R., Ma, Y. and Li, Q. (2017). Effects of pre-sowing irrigation and straw mulching on the grain yield and water use efficiency of summer maize in the North China Plain. Agricultural Water Management, 186, 21-28. https://doi.org/10.1016/j.agwat.2017.02.017

Zhou, G., Zhang, J., Chen, L., Zhang, C. and Yu, Z. (2016). Temperature and straw quality regulate the microbial phospholipid fatty acid composition associated with straw decomposition. Pedosphere, 26, 386-398. https://doi.org/10.1016/S1002-0160(15)60051-0 